\title{
Can indolebutyric and fulvic acids induce adventitious rhizogenesis on mini-cuttings from Brazilian native tibouchinas?
}

\author{
Leandro Porto Latoh ${ }^{1 *}$, Erik Nunes Gomes ${ }^{2}$, Katia Christina Zuffellato-Ribas ${ }^{3}$
}

\begin{abstract}
The use of Brazilian native species for ornamental purposes is a promising alternative for local floriculture. Seeking to contribute with new information in this context, the present study aimed to evaluate the rooting performance of mini-cuttings from three Tibouchina species ( $T$. aff. fothergillae, T. heteromalla and T. moricandiana var. vinacea) as affected by the use of indolebutyric acid (IBA) and fulvic acid (FA). Mini-cuttings with $5 \mathrm{~cm}$ in length were prepared with plant material from clonal mini-hedges and submitted to different treatments as follows: control treatment (T1); 2,000 $\mathrm{mg} \mathrm{L}^{-1}$ IBA (T2); 2,000 mg L-1 FA (T3) and 2,000 $\mathrm{mg} \mathrm{L}^{-1} \mathrm{IBA}+2,000 \mathrm{mg} \mathrm{L}^{-1} \mathrm{FA}$ (T4). Planting was carried out in plastic containers filled with vermiculite, and, after 26 days under greenhouse conditions, the following variables were evaluated: mini-cuttings rooting percentage (RP), roots number (RN), roots length (RL), initial leaves maintenance (ILM) and sprouting (SP). The experiment was conducted under a completely randomized design in a $3 \times 4$ factorial scheme, with four replications and 20 minicuttings per plot. Rooting percentages were higher than $90 \%$ in all three species, regardless of IBA or FA treatments. RP, ILM and SP did not show statistically significant interaction between the treatments. For RN, T2 and T4 promoted the best results on T. aff. fothergillae (12.62 and 14.92, respectively) and T2 resulted in maximum values for T. heteromalla (15.65). For RL, T2 and T4 were statistically superior on T. heteromalla $(9.52$ and $8.20 \mathrm{~cm}$, respectively). The use of IBA and FA is dispensable for rhizogenesis induction on mini-cuttings from the studied species.

Keywords: Tibouchina aff. fothergillae Cogn., Tibouchina heteromalla Cogn., Tibouchina moricandiana var. vinacea Baill., plant propagation.
\end{abstract}

\section{Resumo}

Os ácidos indolbutírico e fúlvico podem induzir rizogênese adventícia em miniestacas de quaresmeiras nativas? $\mathrm{O}$ uso de espécies nativas brasileiras para fins ornamentais é uma alternativa promissora para a floricultura local. Buscando contribuir com novas informações neste contexto, objetivou-se avaliar o desempenho de enraizamento de miniestacas de três espécies de Tibouchina ( $T$. aff. fothergillae, T. heteromalla e T. moricandiana var. vinacea) com o uso de ácido indol butírico (AIB) e ácido fúlvico (AF). Miniestacas com $5 \mathrm{~cm}$ de comprimento foram preparadas com material vegetal oriundo de minijardins clonais e submetidas a diferentes tratamentos: tratamento controle (T1); $2.000 \mathrm{mg} \mathrm{L}^{-1}$ de AIB (T2); $2.000 \mathrm{mg} \mathrm{L}^{-1} \mathrm{de} \mathrm{AF} \mathrm{(T3);} 2.000$ $\mathrm{mg} \mathrm{L}^{-1}$ de $\mathrm{AIB}+2.000 \mathrm{mg} \mathrm{L}^{-1}$ de AF (T4). O plantio foi realizado em tubetes plásticos preenchidos com vermiculita e, após 26 dias em casa de vegetação, foram avaliadas as seguintes variáveis: porcentagem de enraizamento das miniestacas (RP), número de raízes (RN), comprimento de raízes (RL), manutenção das folhas iniciais (ILM) e brotação (SP). O experimento foi conduzido num delineamento inteiramente casualizado, em esquema fatorial $3 \times 4$, com quatro repetições e 20 miniestacas por parcela. Os percentuais de enraizamento foram superiores a 90\% para as três espécies, independentemente dos tratamentos com AIB ou AF. RP, ILM e SP não apresentaram interação estatisticamente significativa entre os tratamentos. Para RN, T2 e T4 promoveram os melhores resultados em $T$. aff. fothergillae (12,62 e 14,92, respectivamente) e T2 resultou em valores máximos para $T$. heteromalla $(15,65)$. Para RL, T2 e T4 foram estatisticamente superiores em T. heteromalla $(9,52$ e 8,20 cm, respectivamente). O uso de AIB e AF é dispensável para indução de rizogênese em miniestacas das espécies estudadas.

Palavras-chave: Tibouchina aff. fothergillae Cogn., Tibouchina heteromalla Cogn., Tibouchina moricandiana var. vinacea Baill., propagação vegetal.

\footnotetext{
${ }^{1}$ Universidade Federal do Paraná, Departamento de Fitotecnia e Fitossanitarismo, Curitiba-Paraná, Brasil.

*Corresponding author: leandrolatoh@outlook.com

${ }^{2}$ Rutgers, The State University of New Jersey, Department of Plant Biology, New Brunswick-New Jersey, United States.

${ }^{3}$ Universidade Federal do Paraná, Departamento de Botânica,Curitiba-Paraná, Brasil

Received July 24, 2018 | Accepted January 21, 2019

Licensed by CC BY 4.0

http://dx.doi.org/10.14295/oh.v25i1.1257
} 


\section{Introduction}

Species of the Melastomataceae family are widely distributed throughout the Brazilian territory, being present in all biomes, with the exception of Caatinga. The species present different population levels according to biome characteristics in each specific region (Goldenberg et al., 2012).

The genus Tibouchina was first described in 1775 by Aublet and was officially recognized around 1875 , by Baillon. Currently, the genus comprises approximately 350 species, and, among them, Tibouchina fothergillae Cogn., Tibouchina heteromalla Cogn. and Tibouchina moricandiana var. vinacea Baill. stand out for their ornamental potential (Aublet, 1775; Lorenzi, 2008).

T. fothergillae shows remarkable ornamental potential, with abundance of purplish flowers at different times of the year. As it grows as a shrub, 1 to 2.5 meters height, it is ideal for landscape projects in reduced spaces (Lorenzi, 2002; Silva and Affonso, 2005).

T. heteromalla is widely used for ornamentation in squares and gardens. This species produces flowers with white base lilac petals, which become reddish after anthesis. Morphologically, it is similar to Tibouchina carvalhoi Wurdack (Freitas et al., 2016).

T. moricandiana var. vinacea is characterized by vigorous branching and production of dark red flowers, especially in times of favorable inductor photoperiod (Lorenzi, 2008).

Species from Melastomataceae family usually present relatively large amounts of aborted seeds and low germination rates (Cézar et al., 2009), which makes their sexual propagation inefficient, considering commercial exploitation. Therefore, the use of vegetative propagation techniques for these species can be a suitable approach.

Vegetative propagation is widely used for ornamental species propagation (Hartmann et al., 2011). This type of propagation comprises diverse techniques such as grafting, layering, air layering, cuttings and mini-cuttings. Vegetative propagation is one of the most important techniques for the regeneration of plants with agronomic interest (Chapman, 1989; Hartmann et al., 2011).

The mini-cutting technique is derived from traditional cuttings propagation. The main advantages of this method in comparison to the use of conventional stem cuttings are: (1) reduction of the required area to obtain viable propagules (adoption of mini-hedges or clonal mini-hedges); (2) shorter period of time for propagules rooting, since it consists of rejuvenated material; and (3) reducing the use of plant growth regulators for rhizogenesis induction (Ferriani et al., 2010). The use of mini-hedges in the vegetative propagation by mini-cuttings presents, additionally, the possibility to control mini-stumps mineral nutrition.

Mineral nutrition influences the availability of several rooting co-factors and its correct management is a fundamental feature for a satisfactory rooting performance of stem mini-cuttings. Zinc ( $\mathrm{Zn})$ is one example of an important micronutrient that works as a rooting co-factor, since it contributes to the biosynthesis of tryptophan, the precursor amino acid for indoleacetic acid (IAA) production in plant tissues. Manganese (Mn), in turn, together with boron (B), promotes the activation of the enzyme IAA-oxidase, whose function is the control of IAA biosynthesis, maintaining its concentration at an adequate level (Hartmann et al., 2011).

The use of plant growth regulators in vegetative propagation aims to provide higher rooting percentages and rhizogenesis speed, quality and uniformity (Hartmann et al., 2011). The regulation of roots elongation exerted by auxin is somewhat paradoxical, since this hormone induces ethylene biosynthesis, which in turn inhibits cell division. However, if ethylene biosynthesis is reduced or blocked, low concentrations of auxin $\left(10^{-10}\right.$ and $\left.10^{-9} \mathrm{M}\right)$ will promote perfect stem tissue differentiation in adventitious roots (Blazich, 1987; Stout et al., 2013).

Besides the use of synthetic auxins, humic substances (HS) with biostimulating action on the growth and development of plants can also be a viable approach to improve vegetative propagation. The benefits of using HS derive from water soluble organic acids from different organic sources that stimulate nutrients absorption (Marchi et al., 2008).

Humic substances can be divided into three operational sub-categories: humic acids, fulvic acids (FA) and humin, main components of soil organic matter (Silva and Mendonça, 2007). The effects on plant metabolism and growth, however, are mainly attributed to fulvic acids (Nardi et al., 2002). Humic substances can regulate the activity of $\mathrm{H}^{+}$pumps, and increase the synthesis of enzymes such as $\mathrm{H}^{+}$ATPases (Canellas et al., 2006). Therefore, it can be assumed that humic substances may present IAAlike activities in plant tissues.

The efficient propagation of species with ornamental potential may directly influence the economy of the floristic and ornamental sectors. Considering the above, the objective of this study was to evaluate the rooting and roots development on mini-cuttings from three Tibouchina species ( $T$. aff. fothergillae, T. heteromalla and T. moricandiana var. vinacea) according to IBA and FA application, alone and in combination, thus recommending a protocol for the species propagation.

\section{Material and Methods}

The experiment was carried out in an artificilly climatized greenhouse $\left(25 \pm 2{ }^{\circ} \mathrm{C}\right.$ and about $85 \%$ air relative humidity) located in the Biological Sciences Division, Federal University of Paraná (UFPR), Curitiba, Parana State, Brazil.

Mini-cuttings from three Tibouchina species ( $T$. aff. fothergillae, T. heteromalla and T. moricandiana var. vinacea) were collected from shoots of mini-stumps approximately two years old The mini-stumps were part of a mini-hedge from cutting technic conducted at open sunlight at the GEPE (Research and Study Group on Cuttings) nursery, located at UFPR, Curitiba, Paraná State, Brazil. The climate of the region is characterized as $\mathrm{Cfb}$, 
according to the Köppen classification. The mini-cuttings were collected during the morning period in the summer of 2017.

During mini-hedge management phase, the mini-stumps were submitted to fertigation every 15 days with $50 \mathrm{~mL}$ each of the following nutrient solution: $4 \mathrm{~g} \mathrm{~L}^{-1}$ ammonium sulfate, triple superphosphate and potassium chloride and 1 $\mathrm{g} \mathrm{L}^{-1}$ FTE BR-10 (7\% Zn, 4\% Fe, 4\% Mn, 0.1\% Mo, 2.5\% $\mathrm{B}$ and $0.8 \% \mathrm{~B}$ ).

Mini-cuttings were made $5 \pm 1 \mathrm{~cm}$ long and with different basal diameter according to the species: $1.5 \mathrm{~mm}$ ( $T$. aff. fothergillae), $2 \mathrm{~mm}$ (T.heteromalla) and 1.3 (T. moricandiana var. vinacea). The propagules were made with a bevel (diagonal) cut at the base and a straight cut at the apex. Two leaves reduced to half their area were kept at the apical region of each mini-cutting.

Mini-cuttings bases were submerged during 10 seconds in $50 \%(\mathrm{v} / \mathrm{v})$ hydroalcoholic solutions containing different treatments as follows: control (T1), 2,000 $\mathrm{mg} \mathrm{L}^{-1} \mathrm{IBA}$ (T2), 2,000 $\mathrm{mg} \mathrm{L}^{-1} \mathrm{FA}(\mathrm{T} 3)$ and 2,000 $\mathrm{mg} \mathrm{L}^{-1} \mathrm{IBA}+2,000 \mathrm{mg}$ $\mathrm{L}^{-1} \mathrm{FA}(\mathrm{T} 4)$. Fulvic acid (10\%) from leonardite was used to perform this study.

After treatments, mini-cuttings were planted in $53 \mathrm{~cm}^{3}$ polypropylene containers with six interior vertical ribs, filled with pre-moistened fine-granulumetry vermiculite. The cone-tainers were kept for 26 days under previously described greenhouse conditions until evaluation.
The following variables were assessed: rooting percentage (percentage of living mini-cuttings with roots at least $2 \mathrm{~mm}$ long [RP]), average number of roots per minicutting $(\mathrm{RN})$, average length of the 3 longest roots per minicutting (RL), percentage of minicuttings that maintained the apical leaves (ILM) and sprouting percentage (SP).

The experimental design was completely randomized in a $3 \times 4$ factorial scheme ( 3 species $x 4$ treatments), with four replications and 20 mini-cuttings per experimental unit, totaling 320 mini-cuttings per species and 960 minicuttings in the experiment. Data were submitted to variance homogeneity analysis by the Bartlett test, variance analysis (ANOVA), and the means were compared by the Tukey test at the $5 \%$ probability level.

\section{Results and Discussion}

According to variance analysis, there was no interaction between species and treatments for RP, SP and ILM. Analyzing the factors in isolation, both the species and treatments with rooting stimulants did not differ among themselves for RP and ILM. T. aff. fothergillae, T. heteromalla and T. moricandiana var. vinacea can be considered as easy rooting species, since they all presented rooting rates superior than $90 \%$ regardless the use of IBA or FA (Table 1).

Table 1. Average rooting (RP), sprouting (SP) and initial leaves maintenance (ILM) on mini-cuttings from different Tibouchina species (T. aff. fothergillae, T. heteromalla and T. moricandiana var. vinacea) submitted to different treatments with indolebutyric acid (IBA) and fulvic acid (FA), after 26 days in artificially climatized greenhouse.

\begin{tabular}{|c|c|c|c|c|}
\hline \multicolumn{2}{|c|}{ Species } & RP (\%) & SP $(\%)$ & ILM (\%) \\
\hline \multicolumn{2}{|c|}{ T. aff. fothergillae } & $95.83 \mathrm{a}$ & $82.81 \mathrm{a}$ & $85.62 \mathrm{a}$ \\
\hline \multicolumn{2}{|c|}{ T. heteromalla } & $95.08 \mathrm{a}$ & $75.00 \mathrm{a}$ & $97.94 \mathrm{a}$ \\
\hline \multicolumn{2}{|c|}{ T. moricandiana var. vinacea } & $90.62 \mathrm{a}$ & $75.00 \mathrm{a}$ & $80.62 \mathrm{a}$ \\
\hline \multicolumn{2}{|c|}{ Rooting stimulants } & RP (\%) & SP (\%) & ILM (\%) \\
\hline Control & & $92.85 \mathrm{a}$ & $84.04 \mathrm{a}$ & $85.35 \mathrm{a}$ \\
\hline $2,000 \mathrm{mg} \mathrm{L}^{-1}$ & IBA & $96.07 \mathrm{a}$ & $67.44 \mathrm{~b}$ & $89.46 \mathrm{a}$ \\
\hline $2,000 \mathrm{mg} \mathrm{L}^{-1}$ & FA & $92.20 \mathrm{a}$ & $85.35 \mathrm{a}$ & $82.73 \mathrm{a}$ \\
\hline $2,000 \mathrm{mg} \mathrm{L}^{-1}$ & $\mathrm{IBA}+\mathrm{FA}$ & $94.40 \mathrm{a}$ & $73.57 \mathrm{ab}$ & $81.36 \mathrm{a}$ \\
\hline \multicolumn{2}{|c|}{ Coefficient of variation (\%) } & 7.24 & 14.76 & 12.93 \\
\hline
\end{tabular}

Means followed by the same lowercase letter in the columns do not differ statistically from each other according to the Tukey test at $5 \%$ probability.

The satisfactory results reported in the present study, together with the published literature regarding Tibouchina species propagation, reinforce that vegetative propagation can be a valuable approach to exploit economically important species.

Corroborating the results from the present study, rooting rates above $85 \%$ were reported on T. moricandiana var. vinacea (Pereira et al., 2015; Latoh et al., 2018) and $T$. fothergillae (Nicknich et al., 2013; Latoh, et al., 2018) stem cuttings regardless IBA application or absence.
The so-called 'easy rooting plants', are those plants whose tissues contain appropriate levels of endogenous substances to induce adventitious rooting, and, therefore, do not need any treatment with exogenous substances, such as synthetic auxins or rooting co-factors, to induce cuttings rhizogenesis (Hartmann et al., 2011). The native species investigated in the present study fit into this definition, and possibly presented ideal levels of auxins and rooting co-factors, since high rooting rates were observed on mini-cuttings. 
The fact that mini-cuttings presented high percentages of original leaves maintenance (above $80 \%$ ) may also be an important factor responsible for high rooting rates, since the leaves are a source of auxins and carbohydrates, among other compounds, which are translocated from the apex to the base of mini-cuttings, stimulating rhizogenesis (Hartmann et al., 2011). It can be inferred that minicuttings from the studied species had high auxin levels due to their reduced rate of foliar abscission. Such a behavior demonstrates maybe that auxin is in significantly higher levels than ethylene (i.e. auxin/ethylene ratio is high), at least in the basal region of leaf petiole.

For Rubus spp cv. Guarani, Tupy and Xavante, leaves are indispensable structures for vegetative propagation, since they provide a significant increase in stem cuttings rooting (Vignolo et al., 2013). Similarly, leaf maitenance is a fundamental feature for rooting and roots growth in Prunus serrulata Lindl. (Fragoso et al., 2015) and Piper amalago L. (Nunes Gomes and Krinski, 2016).

Regarding mini-cuttings sprouting, analyzing the factors in isolation, no difference was observed among the different species. For the treatments with rooting stimulants, however, statistical difference at $5 \%$ probability was detected. T1 (control) and T3 (2,000 $\left.\mathrm{mg} \mathrm{L}^{-1} \mathrm{FA}\right)$ promoted better results than $\mathrm{T} 2\left(2,000 \mathrm{mg} \mathrm{L}^{-1} \mathrm{IBA}\right)$ (Table 1).

The use IBA may have caused alterations in the minicuttings hormonal balance, increasing the auxin/cytokinin ratio, which is known to cause sprouting reduction on vegetative propagules (Hartmann et al., 2011). For Stevia rebaudiana Bert. Stem cuttings, treatment with 2,000 mg $\mathrm{L}^{-1}$ IBA dramatically reduced sprouting percentage, a fact that, according to the authors, was caused because the synthetic auxins in excessive concentrations can have a phytotoxicity effect and inhibit the development of roots and shoots (Pigatto et al., 2018).

Despite the fact some reports show sprouting increase in cuttings with biofertilizers application (Smitha and Umesha et al., 2012; Hakim et al., 2018), in the present study FA did not promote significant improvement of shoots growth on mini-cuttings. This may be attributed to the mini-cuttings appropriate hormonal balance for propagation, since the control treatment presented high levels of both rooting and sprouting. Therefore, the use of FA or any other exogenous substance showed to be unnecessary to stimulate sprouting.

For roots number and length, there was significant interaction between species and treatments with rooting stimulants. Treatment of $T$. heteromalla mini-cuttings with $2,000 \mathrm{mg} \mathrm{L}^{-1}$ IBA promoted longer roots when compared to the treatment with $2,000 \mathrm{mg} \mathrm{L}^{-1} \mathrm{FA}$ and the control. The use of 2,000 $\mathrm{mg} \mathrm{L}^{-1} \mathrm{IBA}+2,000 \mathrm{mg} \mathrm{L}^{-1} \mathrm{FA}$ was superior to the control treatment but did not differ from treatments with FA or IBA alone. For the other studied species, the treatments did not influence roots length. Among the species, regardless of the treatments, T. moricandiana var. vinacea showed lower results, demonstrating relative slow adventitious roots growth (Table 2).

Table 2. Average roots length (RL) and roots number (RN) on mini-cuttings from different Tibouchina species (T. aff. fothergillae, T. heteromalla and T. moricandiana var. vinacea) in interaction with different treatments with indolebutyric acid (IBA) and fulvic acid (FA), after 26 days in artificially climatized greenhouse.

\begin{tabular}{|c|c|c|c|c|c|}
\hline & \multirow{2}{*}{ Species/ Treatments } & \multirow{2}{*}{ Control } & $2,000 \mathrm{mg} \mathrm{L}^{-1}$ & $2,000 \mathrm{mg} \mathrm{L}^{-1}$ & $2,000 \mathrm{mg} \mathrm{L}^{-1}$ \\
\hline & & & IBA & FA & IBA/FA \\
\hline \multirow{4}{*}{ 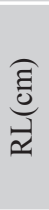 } & $T$. aff. fothergillae & $7.72 \mathrm{aA}$ & $8.25 \mathrm{aA}$ & $7.14 \mathrm{aA}$ & $7.71 \mathrm{aA}$ \\
\hline & T. heteromalla & $6.08 \mathrm{aC}$ & $9.52 \mathrm{aA}$ & $6.98 \mathrm{aBC}$ & $8.20 \mathrm{aAB}$ \\
\hline & T. moricandiana var. vinacea & $3.30 \mathrm{bA}$ & $3.01 \mathrm{bA}$ & $2.81 \mathrm{bA}$ & $3.76 \mathrm{bA}$ \\
\hline & Coefficient of variation (\%) & 17.41 & & & \\
\hline \multirow{4}{*}{ 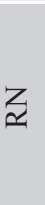 } & T. aff. fothergillae & $8.00 \mathrm{aB}$ & $12.62 \mathrm{bA}$ & $8.37 \mathrm{aB}$ & $14.91 \mathrm{aA}$ \\
\hline & T. heteromalla & $6.81 \mathrm{aC}$ & $15.65 \mathrm{aA}$ & $8.41 \mathrm{aC}$ & $11.86 \mathrm{bB}$ \\
\hline & T. moricandiana var. vinacea & $8.18 \mathrm{aA}$ & $10.21 \mathrm{bA}$ & $8.71 \mathrm{aA}$ & $10.97 \mathrm{bA}$ \\
\hline & Coefficient of variation (\%) & \multicolumn{4}{|c|}{15.96} \\
\hline
\end{tabular}

Means followed by the same capital letters in the rows and lowercase letters in the columns do not differ statistically from each other according to the Tukey test at $5 \%$ probability.

This internal regulation of roots elongation by auxin is highly variable, depending on the endogenous hormone concentration and sensitivity of each species/genotype and, therefore, the appropriate concentration of plant growth regulators to stimulate rooting and roots growth, if necessary, should be studied for each species/genotype. In $P$. serrulata stem cuttings, for example, Fragoso et al. (2017) reported that concentrations of 750 and $1,000 \mathrm{mg}$ $\mathrm{L}^{-1}$ IBA promoted longer roots. For stevia propagation, in turn, roots number and length reached maximum values at concentrations of 1,250 and $700 \mathrm{mg} \mathrm{L}-1$ IBA, respectively (PIGATTO et al., 2018).

Regarding roots number, $T$. aff. fothergillae had better results when submitted to treatments with $2,000 \mathrm{mg} \mathrm{L}^{-1}$ IBA and 2,000 $\mathrm{mg} \mathrm{L}^{-1} \mathrm{IBA}+\mathrm{FA}$. T. heteromalla presented superior results when submitted treated exclusively with 2,000 $\mathrm{mg} \mathrm{L}^{-1}$ IBA and T. moricandiana var. vinacea did not show variations in roots number as a function of treatments 
with rooting stimulants. $T$. aff. fothergillae presented the highest RN among the studied species when treated with 2,000 $\mathrm{mg} \mathrm{L}^{-1} \mathrm{IBA}+\mathrm{FA}$, whereas $T$. heteromalla was superior to the others when IBA was applied alone (Table 2).

It is important to note that producing lateral roots will increase nutrient uptake by increasing root surface area (Zonta et al., 2006). Therefore, the higher the number of roots per mini-cuttings, the greater the efficiency of the plant in absorbing minerals available in the soil nutrient solution.

IBA effects on roots number can vary dramatically according to the species to be studied. For Varronia curassavica Jacq. stem cuttings, 3,000 $\mathrm{mg} \mathrm{L}^{-1}$ IBA promoted better results than the control treatment (Bischoff et al., 2017), whereas to other species such as Drimys brasiliensis Miers (Zem et al., 2015) and Annona crassiflora Mart. (Pimenta et al., 2017), IBA had no effects on this variable. This reinforces the demand for specific studies in agronomic important and/or potential plant species.

Nomura et al. (2012), affirm that the use of biofertilizer based on humic substances improves the acclimatization of micropropagated Musa spp. plantlets, considerably increasing roots fresh and dry biomass. The increase in $\mathrm{H}^{+}$ pumps activity elicited by humic substances resembles the IAA mode of action, favoring the induction of lateral roots and, therefore, increasing the roots system surface area (Canellas et al., 2006).

Despite the positive effects reported in scientific literature, in the present study, the use of FA on Tibouchina species mini-cuttings did not differ from the control treatment for none of the analyzed variables. Because it is a relatively new technology in vegetative propagation and species tend to have different tissue sensibility to rooting stimulants, future studies with on different FA concentrations and modes of application are necessary to state their activity in the studied species.

\section{Conclusions}

T. aff. fothergillae, T. heteromalla and T. moricandiana var. vinacea can be considered easy rooting species, since mini-cuttings from these plants reach rooting rates superior than $90 \%$ without the need of IBA or FA application.

The use of $2,000 \mathrm{mg} \mathrm{L}^{-1}$ IBA or $2,000 \mathrm{mg} \mathrm{L}^{-1}$ IBA + $2,000 \mathrm{mg} \mathrm{L}^{-1} \mathrm{FA}$ promotes higher roots number in $T$. aff. fothergillae. For $T$. heteromalla, $2,000 \mathrm{mg} \mathrm{L}^{-1} \mathrm{IBA}$ is recommended to obtain higher roots number and length. $T$. moricandiana var. vinacea mini-cuttings are not affected by the use of IBA or FA.

\section{Author contribution}

L.P.L. ${ }^{0000-0002-6450-2347}$ : study conception and design, acquisition, analysis and interpretation of data, manuscript draft and review. E.N.G. ${ }^{0000-0002-7999-070 x}$ : Interpretation of data, manuscript draft and critical review. K.C.Z.R. ${ }^{0000-0001-6320-5773}$ : study conception and design, manuscript critical review.

\section{Acknowledgements}

The authors would like to acknowledge the GEPE (Research and Study Group on Cuttings) and UFPR (Federal University of Paraná) for providing the infrastructure used in this research and the Brazilian National Council for Scientific and Technological Development $(\mathrm{CNPq})$ and Federal Agency for Support and Evaluation of Graduate Education (CAPES), by sponsorship of the research and scholarships granted.

\section{References}

AUBLET, J.B.C.F. Histoire dês plantes de la Guiane Françoise. Londres, Paris: Pierre-Françoise Didot Jeune, 1775. 621 p. vol.1.

BISCHOFF, A.M.; VENDRAMIM, D.W.; NUNES GOMES, E.; ENGEL, M.L.; MAGGIONI, R.A.; ZUFFELLATO-RIBAS, K.C. Rooting of black sage cuttings according to different indole butyric acid concentrations and number of leaves. Revista de Ciências Agroveterinárias, v.16, n.1, p.41-47, 2017. DOI: http:// dx.doi.org/10.5965/223811711612017041.

BLAZICH, F.A. Chemicals and formulations used to promote adventitious rooting. In: DAVIES, T.D.; HAISSIG, B.E.; SANKHLA, N. (Eds.). Adventitious root formation in cuttings. Portland: Dioscorides Press, 1987. p.132-149.

CANELLAS, L.P.; ZANDONADI, D.B.; OLIVARES, F.L.; FAÇANHA, A.R. Efeitos fisiológicos de substâncias húmicas - $\mathrm{O}$ estimulo às $\mathrm{H}^{+}$ATPases. In: FERNANDES, M.S. Nutrição Mineral de Plantas. Viçosa: Sociedade Brasileira de Ciência do Solo, 2006. p.175-200.

CÉZAR, T.M.; SOUZA, F.C.; MACIEL, R.T.; DEMBISKI, W.; ZUFFELLATO-RIBAS, K.C.; RIBAS, L.; KOEHLER, H.S. Estaquia e alporquia de Tibouchina fothergillae (D.C.) Cogn. (Melastomataceae) com aplicação de ácido naftaleno acético. Scientia Agrária, v.10, n.6, p.463-468, 2009. DOI: http://dx.doi.org/10.5380/rsa.v10i6.15719.

CHAPMAN, D.J. Consider sofwood cuttings for tree propagation. Journal Rochester, v.15, p.45-49, 1989.

FERRIANI, A.P.; ZUFFELLATO-RIBAS, K.C.; WENDLING, I. Miniestaquia aplicada a espécies florestais. Agro@mbiente On-line, v.4, n.2, p.102-109, 2010. DOI: http://dx.doi.org/10.18227/1982-8470ragro.v4i2.363

FRAGOSO, R.O.; STUEPP, C.A.; RICKLI, H.C.; ZUFFELLATO-RIBAS, K.C.; KOEHLER, H.S. Maximum efficiency concentration of indole butyric acid in promoting the rooting of Japanese Flowering Cherry. Ciência Rural, v.47, n.1, p.1-6, 2017. DOI: http://dx.doi. org/10.1590/0103-8478cr20150894 
FRAGOSO, R.O.; WITT; N.G.D.P.; OBRZUT, V.;VALÉRIO, S.; ZUFFELLATO-RIBAS, K.C.; STUEPP, C.A. Maintenance of leaves and indolebutyric acid in rooting of juvenile Japanese Flowering Cherry cuttings. Revista Brasileira de Ciências Agrárias, v.10, n.1, p.97-101, 2015. DOI: http://dx.doi.org/10.5039/ agraria.v10i1a5111

FREITAS, J.G.; SANTOS, A.K.A.; GUIMARÃES, P.J.F.; OLIVEIRA, R.P. FLORA DA BAHIA: MeslatomataceaeTibouchina s.l. Sitientibus série Ciências Biológicas, v.16, n.1, p.1-46, 2016. DOI: http://dx.doi.org/10.13102/scb1111

GOLDENBERG, R.; BAUMGRATZ, J.F.A.; SOUZA, M.L.D.R. Taxonomia de Melastomataceae no Brasil: retrospectiva, perspectivas e chave de identificação para os gêneros. Rodriguésia, v.63, n.1, p.145-161, 2012. DOI: http://dx.doi.org/10.1590/S217578602012000100011

HAKIM, A.; JAGANATH, S.; HONNABYRAIAH, M.K.; KUMAR, S.M.; KUMAR, S. A.; DAYAMANI, K.J. Influence of biofertilizer and auxin on growth and rooting of pomegranate (Punica granatum L.) cuttings. International Journal of Current Microbiology and Applied Sciences, v.7, n.2, p.1187-1193, 2018. DOI: https://doi.org/10.20546/ ijcmas.2018.702.146

HARTMANN, H.T.; KESTER, D.E.; DAVES JUNIOR, F.T.; GENEVE, R.L. Techniques of Propagation by Cuttings. In: HARTMANN, H.T.; KESTER, D.E.; DAVES JUNIOR, F.T.; GENEVE, R.L. Plant Propagation: Principles and Practices. Boston: Presentice Hall, 8 ed., 2011. p.344-414.

LATOH, L.P.; DALLAGRANA, J.F.; PORTES, D.C.; MAGGIONI, R.A.; ZUFFELLATO-RIBAS, K.C. Propagação vegetativa via estaquia caulinar de espécies do gênero Tibouchina spp. Nas estações do ano. Revista Eletrônica UERGS, v.4, n.1, p.17-41, 2018. DOI: http:// dx.doi.org/10.21674/2448-0479.41.17-41

LORENZI, H. Árvores brasileiras: Manual de Identificação e Cultivo de Plantas Arbóreas Nativas do Brasil. 5.ed. Nova Odessa: Instituto Plantarum, 2008. 262p.

MARCHI, E.C.S.; ALVARENGA, M.A.R.; MARCHI, G.; SILVA, C.A.; SOUZA FILHO, J.L. Efeito da adubação orgânica sobre as frações de carbono de solos cultivados com alface americana. Ciência e Agrotecnologia, v.32, n. 6, p.1760-1766, 2008. DOI: http://dx.doi.org/10.1590/ S1413-70542008000600013

NARDI, S.; PIZZEGHELLO, D.; MUSCOLO, A.; VIANELLO, A. Physiological effects of humic substances on higher plants. Soil Biology and Biochemistry, v.34, n.11, p.1527-1536, 2002. DOI: https://doi.org/10.1016/ S0038-0717(02)00174-8
NICKNICH, R.; WEISER, A.H.; ZUFFELLATO-RIBAS, K.C. Influência do ácido indolbutírico no enraizamento de estacas de quaresmeiras. Scientia Agraria, v.14, n.2, p.6567, 2013. DOI: http://dx.doi.org/10.5380/rsa.v14i2.40931

NOMURA, E.S.; JUNIOR, E.R.D.; FUSITANI, E.J.; SAES, L.A.; JENSEN, E. Aclimatação de mudas micropropagadas de bananeira 'Grand Naine' com aplicação de biofertilizante em duas estações do ano. Ceres, v.59, n.4, p.518-529, 2012. DOI: http://dx.doi.org/10.1590/ S0034-737X2012000400013

NUNES GOMES, E.; KRINSKI, D. Propagação vegetativa de Piper amalago L. (Piperaceae) em função de tipos de estaca e substratos. Cultura Agronômica, v.25, n.2, p.199$210,2016$.

PEREIRA, M.O.; GRABIAS, J.; ZUFFELLATO-RIBAS, K.C.; NAVROSKI, M.C. Enraizamento de estacas de Tibouchina moricandiana var. vinacea em função da forma de aplicação e concentrações de AIB. Revista de Ciências Agroveterinárias, v.14, n.3, p.210-216, 2015. DOI: http:// dx.doi.org/10.5965/223811711432015210

PIGATTO, G.B.; NUNES GOMES, E.: TOMASI, J.C.; FERRIANI, A.P.; DESCHAMPS, C. Effects of indolebutyric acid, stem cutting positions and substrates on the vegetative propagation of Stevia rebaudiana Bertoni. Revista Colombiana de Ciencias Hortícolas, v.12, n.1, p.202-211, 2018. DOI: http://dx.doi.org/10.17584/ rcch.2018v12i1.6631

PIMENTA, A.C.; AMANO, E.; ZUFFELLATO-RIBAS, K.C. Estaquia e anatomia caulinar de Annona crassiflora Mart. Caderno de Ciências Agrárias, v.9, n.2, p.1-7, 2017.

SILVA, I.R.; MENDONÇA, E.S. Matéria orgânica do solo. In: NOVAIS, R.F.; ALVAREZ, V.H.; BARROS, N.F.; FONTES, R.L.; CANTARUTTI, R.B.; NEVES, J.C.L. Fertilidade do solo. Viçosa: Sociedade Brasileira de Ciência do Solo, 2007. p.275- 374

SILVA, C.V.; AFFONSO, P. Levantameto da Tibouchina Aubl. (Melastomataceae) no Parque Estadual da Serra do Mar. Revista do Instituto Florestal, v.17, n.2, p.195-206, 2005.

SMITHA, G.R.; UMESHA, K. Vegetative propagation of stevia [Stevia rebaudiana (Bertoni) Hems.] through cuttings. Journal of Tropical Agriculture, v.50, n.1, p.7275,2012 .

STOUT, R.G.; BERNASCONI, P.; MURPHY, A. AUXINA: O Primeiro Hormônio do Crescimento Vegetal Descoberto. In: TAIZ. L.; ZEIGER. E. Fisiologia vegetal, 5ed. Porto Alegre: Artmed, 2013. 918p. 
VIGNOLO, G.K.; PICOLOTTO, L.; GONÇALVES, M.A.; PEREIRA, I.S.; ANTUNES, L.E.C. Presença de folhas no enraizamento de estacas de amoreira-preta. Ciência Rural, v.44, n.3, p.467-472, 2014. DOI: http://dx.doi.org/10.1590/ S0103-84782014000300013

ZEM, L.M..; WEISER, A.H.; ZUFFELLATO-RIBAS, K.C.; RADOMSKI, M.I. Estaquia caulinar herbácea e semilenhosa de Drimys brasiliensis. Revista Ciência Agronômica, v.46, n.2, p.396-403, 2015. DOI: http:// dx.doi.org/10.5935/1806-6690.20150019
ZONTA, E.; BRASIL, F.C.; GOI, S.R.; ROSA, M.M.T. O Sistema radicular e suas interações com o ambiente edáfico. In: Fernandes, M.S. Nutrição Mineral de Plantas. Viçosa: Sociedade Brasileira de Ciência do Solo, 2006. p.7-52. 